\title{
Phenotypic and molecular characterization of different isolates of Lactobacillus plantarum from four Nigerian fermented foods for use as probiotics in aquaculture
}

\section{Daniel Olusegun Diyaolu ${ }^{1}, *$, Fatuyi Olanipekun Ekundayo ${ }^{2}$, Emmanuel Adedayo Fasakin ${ }^{1}$ and Olabode Thomas Adebayo ${ }^{1}$}

${ }^{1}$ Department of Fisheries and Aquaculture Technology, Federal University of Technology, P. M. B. 704 Akure, Nigeria.*Email: diyaolusegun@yahoo.com.

${ }^{2}$ Department of Microbiology, Federal University of Technology, P. M. B. 704 Akure, Nigeria.

\begin{abstract}
This study aimed at identifying Lactobacillus plantarum from fermented maize, sorghum, soyabeans and cassava, using both phenotypic method and 16S RNA sequencing, as well as determining similarity or otherwise among recovered isolates. Biochemical characterization of isolates recovered from these fermented foods revealed that L. plantarum occurred in all fermented food examined, with slight variation in their abilities to ferment some sugars (arabinose, dulbitol and mannitol). These phenotypically identified isolates were also confirmed to be L. plantarum by $16 \mathrm{~S}$ rRNA sequencing, having close relatedness $(\geq 95 \%)$ with other isolates available in the gene bank. However, intragenomic heterogeneity of the 16S rRNA gene was observed among these L. plantarum isolates. The result obtained in this finding pinpoints the need to evaluate the beneficial effects each strain of $L$. plantarum may possess as promising probiotics, rather than generalising common effects for all strains of this bacterial species.
\end{abstract}

Keyword: Fermented foods; Characterisation; Sequencing; Lactobacilli.
Received

May 26, 2018

Accepted

August 20, 2018

Released

August 31, 2018

Full Text Article

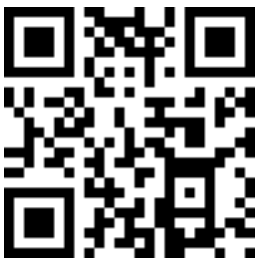

ORCID

(D) 0000-0002-6068-506X

Daniel Olusegun Diyaolu

(D) 0000-0001-7774-7696

Fatuyi Olanipekun Ekundayo

0000-0001-6009-043X

Emmanuel Adedayo

Fasakin

(D) 0000-0002-7380-8612

Olabode Thomas

Adebayo 


\section{Introduction}

Recent advances in gut - microbe interactions have highlighted the importance of gut microbiota in the growth and wellbeing of cultured fish (Nayak, 2010). This understanding has aided the current practice of artificial modulation of fish gut microbiota toward beneficial communities through administration of probiotics in feeds or water. The potentials of several probiotic microorganisms, especially lactic acid bacteria (LAB), as a common tool for prevention and control of various diseases, as well as improvement in digestion, growth and survival of various fish species, have been demonstrated by researchers (Cruz et al., 2012; Merrifield et al., 2014; Ringø et al., 2014)

Lactobacillus plantarum, being an important member of $\mathrm{LAB}$, is a rodshaped, gram-positive, non-pathogenic bacterium. This bacterium is highly versatile and found in many different ecological niches such as fermented foods from vegetables, meat, fish, and dairy as well as in the gastro-intestinal tract of humans, terrestrial and aquatic animals (Siezen and van Hylckama Vlieg, 2011) Several strains of this bacterial species have been claimed to posses valuable health promoting (probiotic) features (da Silva et al., 2014; Guidone et al., 2014), including immune-modulation of the host, competitive exclusion of pathogens, production of antimicrobial substances, organic acids, bacteriocins (Molin, 2001).

Generally, it is essential to properly characterize microorganisms intended for use as probiotics to avoid confusions ensuing from improper identification, since it has been proven that bacterial strains of the same species may exert different effects on the host (Vankerckhoven et al., 2008). Until recently, characterization and identification of lactobacilli have been undertaken mostly by phenotypic methods, such as carbohydrate fermentation, cellular morphology and
Gram staining. Phenotypic methods of bacterial identification are still in use, but these conventional methods have some drawbacks, as they are time consuming and may be inaccurate. Because most lactic acid bacteria have been found to display a range of subspecies level population structures, it is now considered that the identification of Lactobacillus species by biochemical methods alone is not reliable (Schleifer et al., 1995). Appropriate cultureindependent approaches, such as $16 \mathrm{~S}$ rRNA sequencing, have been recommended to facilitate accurate assignment of microorganism to species level (FAO/WHO, 2006; Naser et al., 2007).

Therefore, the aim of this study is, in addition to phenotypic identification, to genotypically characterize L. plantarum isolates from four Nigerian fermented foods using 16S rRNA sequencing. We intend to determine the phylogenetic relationships between bacterial sequences isolated in the present study and sequences of other related bacteria available in gene banks. This work is to serve as preliminary study for examining best isolates of L. plantarum that can serve as probiotics for fish farming.

\section{Materials and methods}

\section{Sample collection and Lactobacillus isolation}

The ingredients (maize, sorghum, soyabeans, and cassava) used for fermentation in this study were sourced from local farmers. Fifty grammes of maize, sorghum, soyabeans and pealed cassava were washed and soaked differently in $100 \mathrm{ml}$ water in plastic containers covered with lids. The ingredients were left to ferment for three days simulating the techniques employed for traditional fermentation. $5 \mathrm{~g}$ of fermented products from each sample were aseptically weighed in an electronic balance (METLAR MT-301) and homogenized in mortal and pestle. The 
homogenates were appropriately dissolved in $10 \mathrm{~mL}$ sterile saline solution ( $9 \mathrm{~g}$ of $\mathrm{NaCl}$ per litre of water). $0.1 \mathrm{~mL}$ of $10^{-4}$ and $10^{-5}$ dilutions of each of these samples was transferred into sterile Petri-dishes. The de-Mann Rogosa and Sharpe (MRS) agar LAB093 (Lab M Ltd, United Kingdom) - a selective medium for the enumeration of lactobacilli in food, was used. $5 \mathrm{~mL}$ of sterile MRS agar was poured on each petri dish, allowed to set and incubated under anaerobic environment of $\mathrm{CO}_{2}$ at $37^{\circ} \mathrm{C}$ for $48 \mathrm{~h}$. The colonies in each plate were used for further tests.

\section{isolates}

Phenotypic characterization of

Discreet colonies from each Petri dish were purified by sub-culturing them on fresh MRS agar plate. A pure culture of each isolates was stored in MRS slant at $4{ }^{\circ} \mathrm{C}$ in a refrigerator prior to characterization and identification. Phenotypic tests such as Gram staining, catalase, growth at $15{ }^{\circ} \mathrm{C}$ and $45{ }^{\circ} \mathrm{C}$, and ability to utilize sugars (glucose, fructose, arabinose, sucrose, lactose, maltose, raffinose, mannitol, inositol and dulbitol) was carried out to identify isolated organisms, using the methods recommended by Fontana et al. (2005). All isolates identified thus as Lactobacillus plantarum were used for further tests.

\section{Molecular characterization of phenotypically identified $L$. plantarum DNA extraction \\ Overnight (18-24 h old) MRS broth cultures of phenotypically identified L. plantarum from each of the fermented foods examined were used for DNA extraction. $1 \mathrm{ml}$ of each broth was centrifuged at $14,000 \times \mathrm{g}$ for $30 \mathrm{~s}$ to pellet the cells, while the supernatant was carefully poured off. DNA extractions were done according to manufacturer's instructions for Bacterial Genomic DNA Isolation kit (Norgen Biotek Corporation). Extracted DNA product was then used for polymerase chain}

reaction (PCR) and other downstream applications.

\section{PCR product amplification and gel electrophoresis}

Amplification of $16 \mathrm{~S}$ rRNA gene of the extracted DNA was performed using the primers 16SF (GTGCCAGCACCGCTAA) and 16SR (AGACCCGGGAACGTATTCAC) for forward and reverse reactions, respectively. The DNA was subjected to the following cocktail mix $\left(\begin{array}{lll}10 & \mu \mathrm{L}\end{array}\right)$, consisting of $2.0 \mu \mathrm{L}$ of $10 \mathrm{ng} / \mu \mathrm{L}$ DNA,1.0 $\mu \mathrm{L}$ of $10 \times$ PCR buffer, $1 \mu \mathrm{L}$ of $25 \mathrm{mM}$ Mgc12, $1 \mu \mathrm{L}$ DNSO, $0.8 \mu \mathrm{L} 25 \mathrm{Mm}$ dNTPs, $0.1 \mu \mathrm{l}$ of $5 \mathrm{u} / \mu \mathrm{L}$ Taq, $0.5 \mu \mathrm{L}$ of each of the primers and $3.1 \mu \mathrm{L}$ of $\mathrm{H}_{2} \mathrm{O}$. The PCR condition involved initial denaturation at $94{ }^{\circ} \mathrm{C}$ for $5 \mathrm{~min}, 36$ cycles of denaturation $94{ }^{\circ} \mathrm{C}$ for $30 \mathrm{sec}$, annealing at $55{ }^{\circ} \mathrm{C}$ for $30 \mathrm{~s}$, extension at $72{ }^{\circ} \mathrm{C}$ for $45 \mathrm{~s}$, final extension step at $72{ }^{\circ} \mathrm{C}$ for $7 \mathrm{~min}$, and holding temperature at $10^{\circ} \mathrm{C}$.

The amplicon from the reaction above was examined using agarose gel electrophoresis. $1.5 \mathrm{~g}$ agarose powder was weighed into a conical flaskand dissolved with $100 \mathrm{~mL}$ tris-acetic-EDTA (TAE) buffer solution. The mixture was melted in a microwave oven for $2 \mathrm{~min}$ and allowed to cool, after which $15 \mu \mathrm{L}$ ethidium bromide was added. The solution was poured into a gel caster and allowed to solidify, and the comb was removed. The gel caster was placed into the gel tank containing TAE buffer, while the product sample with loading dye was carefully poured into the well created by the comb in the gel. The gel caster was run at $100 \mathrm{~V}$ for $90 \mathrm{~min}$, and visualization was made under UV light illumination.

\section{PCR product purification and sequencing}

The protocol for purification of PCR product involved adding 2 volumes $(20 \mu \mathrm{L})$ of absolute ethanol to PCR product and incubating at room temperature for $5 \mathrm{~min}$. The mixture was centrifuged at $10,000 \mathrm{rpm}$ for $15 \mathrm{~min}$ after which the supernatant was 
carefully decanted. 2 volume of $70 \%$ ethanol was added for $5 \mathrm{~min}$ and then centrifuged at $10,000 \mathrm{rpm}$ for $15 \mathrm{~min}$. The supernatant was decanted and the mixture was air dried to remove the liquid. $10 \mu \mathrm{L}$ of ultrapure water was added, and the amplicon was checked on $1.5 \%$ agarose.

The purified PCR products were used for the sequencing reaction following protocol of BigDye Terminator v3.1 Sequencing Kit (Applied Biosystems). The products were loaded on the 3130xl Genetic Analyzer (Applied Biosystems) for sequencing, and the procedure followed the manufacturer's instructions.

\section{analysis}

Nucleotide blast and phylogeny

The nucleotide sequences of each isolate were analysed on Basic Local Alignment Search Tool (BLAST) of the National Center for Biotechnology Information (NCBI; http://www.ncbi. nlm.nih.gov) for similarity search. The 16S rRNA gene sequences were compared with those of other similar strains that were most closely related. After the blast, the nucleotides of two closely related L.plantarum $(\geq 95 \%$ similarities) with each isolate were retrieved. These retrieved nucleotide sequences together with those under study were then imported into BLAST ONE CLICK software (http://www.phylogeny.fr/simple_phylo geny.cgi) and aligned, after which a neighbour-joining phylogeny tree was constructed (Castresana, 2000; Guindon and Gascuel, 2003; Edgar, 2004; Anisimova and Gascuel, 2006; Chevenet, 2006; Deeper et al., 2008; Deeper et al., 2010).

\section{Accession numbers of the submitted nucleotides}

The nucleotide sequences of the 16S rRNA gene of phenotypically identified L. plantarum isolates from fermented maize, sorghum, soyabeans and cassava were submitted to the DNA
Data Bank of Japan (DDBJ), after which each of the isolates were accorded ascension numbers.

\section{Results}

\section{Phenotypic identification of isolated bacteria}

The phenotypic characterizations of the isolates were presented in Table 1. The results showed that Lactobacillus plantarum occurred in all the four fermented foods examined. Three of the isolates were unidentified due to their high inconsistencies in sugar fermentation, while the remaining isolates were identified presumptively as Lactobacillus fermentum (occurring in maize, sorghum and cassava), Lactobacillus brevis (occurring in soyabeans and cassava) and Lactobacillus amylophillus only in sorghum.

Irrespective of the source, all identified isolates utilized glucose, inositol and sucrose. In addition, all L. plantarum isolated in this study were, able to utilize raffinose and fructose but not maltose and lactose, and were inconsistent in arabinose, dulbitol and mannitol utilization. Similar pattern of sugar fermentations, in which isolated bacteria fermented some sugars but are inconsistent in the fermentation of others, were observed in other lactobacilli identified as L.brevis, L. fermentum and L. amylophillus.

The four strains of presumptive L. plantarum recovered from fermented maize, sorghum, soyabeans and cassava, designated as LBPLMAF02, LBPLSHF03, LBPLSYF05 and LBPLCAF06 respectively, were selected for genotypic analysis.

\section{Genotypic identification of phenotypically identified L. plantarum isolates}

The amplified PCR product from each isolate were detected and presented as unambiguous visible band in each lane on $1.5 \%$ agarose gel electrophoresis (Figure 1). The fragment lengths of the 
amplicons of $16 \mathrm{~S}$ region of four selected isolates were uniform, measuring about $850 \mathrm{bp}$. The amplicon quality and other parameters of each isolate were presented in Table 2, with isolates labelled as LBPLMAFO2 and LBPLSGO3 having highest and lowest concentrations of nucleic acid, respectively.

Table 1. Phenotypic characterizations of different Lactobacillus strains isolated from fermented foods.

\begin{tabular}{|c|c|c|c|c|c|c|c|c|c|c|c|c|c|c|c|c|c|}
\hline \multirow{2}{*}{\multicolumn{2}{|c|}{ Fermented foods }} & \multirow{2}{*}{$\begin{array}{c}\text { Isolate } \\
\text { Label }\end{array}$} & \multirow{2}{*}{$\begin{array}{c}\text { Gram } \\
\text { rxn. }\end{array}$} & \multirow[b]{2}{*}{ Cat } & \multirow{2}{*}{$\begin{array}{l}\text { Growth } \\
\text { at } 15^{\circ} \mathrm{C}\end{array}$} & \multirow{2}{*}{$\begin{array}{l}\text { Growth } \\
\text { at } 45^{\circ} \mathrm{C}\end{array}$} & \multicolumn{10}{|c|}{ Fermentation of } & \multirow{2}{*}{$\begin{array}{l}\text { Identified } \\
\text { bacteria }\end{array}$} \\
\hline & & & & & & & Glu & Fru & Lac & Dul & Man & Ino & Mal & Ara & Suc & Raff & \\
\hline \multicolumn{2}{|l|}{ Maize [0gi] } & MA & $+\mathrm{R}$ & - & + & - & + & + & - & - & - & + & - & - & + & + & $L$ plantarum \\
\hline \multicolumn{2}{|l|}{ Maize (Ogi) } & MB & $+\mathrm{R}$ & - & + & + & - & & + & - & - & - & + & + & - & + & unidentified \\
\hline \multicolumn{2}{|l|}{ Maize (Ogi) } & MC & $+R$ & $\cdot$ & + & - & + & $\cdot$ & + & + & + & + & + & + & + & & L. fermentum \\
\hline $\begin{array}{l}\text { Sorghum } \\
\text { baba) }\end{array}$ & fogi & SA & $+\mathrm{R}$ & - & - & + & + & $\cdot$ & + & + & + & + & + & + & + & - & L. fermentum \\
\hline $\begin{array}{l}\text { Sorghum } \\
\text { baba) }\end{array}$ & logi & SB & $+R$ & - & + & - & + & + & - & + & - & + & - & + & + & + & $L$ plantarum \\
\hline $\begin{array}{l}\text { Sorghum } \\
\text { baba) }\end{array}$ & fogi & SC & $+\mathrm{R}$ & - & - & + & - & $\cdot$ & + & + & - & $\cdot$ & + & + & - & - & unidentified \\
\hline $\begin{array}{l}\text { Sorghum } \\
\text { baba) }\end{array}$ & logi & SD & $+R$ & - & - & + & + & - & + & - & + & - & - & - & + & - & L amylophillus \\
\hline $\begin{array}{l}\text { Soyabeans } \\
\text { soya) }\end{array}$ & (Iru & SYA & $+\mathrm{R}$ & $\cdot$ & + & $\cdot$ & + & + & $\cdot$ & $\cdot$ & - & + & - & $\cdot$ & + & + & $L$ plantarum \\
\hline $\begin{array}{l}\text { Soyabeans } \\
\text { soya) }\end{array}$ & (Iru & SYB & $+\mathrm{R}$ & - & - & + & + & + & + & + & - & $\cdot$ & - & + & + & + & L. brevis \\
\hline Cassava (fufu & & $\mathrm{CA}$ & $+\mathrm{R}$ & - & + & - & + & + & + & + & - & - & - & + & + & + & L. brevis \\
\hline Cassava (fufu & & $\mathrm{CB}$ & $+\mathrm{R}$ & - & + & - & + & + & - & - & + & + & - & - & + & + & $L$ plantarum \\
\hline Cassava (fufu & & CC & $+\mathrm{R}$ & $\cdot$ & - & + & + & $\cdot$ & + & + & + & + & + & + & + & . & L. fermentum \\
\hline Cassava (fufu & & $\mathrm{CD}$ & $+R$ & - & - & + & + & + & + & - & - & - & + & - & - & . & unidentified \\
\hline
\end{tabular}

NB: Glu - glucose; Flu - fructose; Ara - arabinose; Suc - sucrose; Lac - lactose; Mal - maltose; Raf rfaffinose; Man - mannitol; Ino - inositol; Dul - dulbitol; Cat - catalase; +R - Gram positivr rods; ""= negative reaction; "+"= positive reaction

Following recommendations of Fontana et al. (2005) for gram positive bacteria, we identified the four isolates under study as Lactobacillus plantarum based on comparison of their nucleotides with those of the closest species on the Gene bank (NCBI), with similarity percentages greater than $95 \%$ and $\mathrm{E}$ value of 0 for all isolates (Table 3). The phylogenetic tree (Figure 2) showed seven distinct groups indicating intragenomic diversity between the nucleotides of the four isolates and those selected from the Gene Bank.

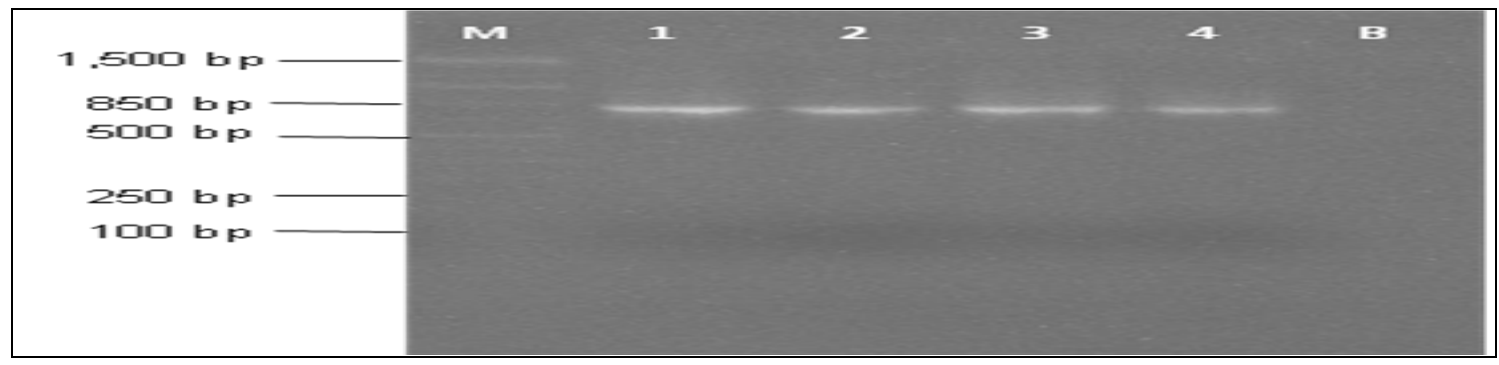

Figure 1. Agarose gel electrrophoressis of purified PCR products of L. plantarum isolates. Lane M 100-base-pair (bp) DNA ladder; lane 1 - LBPLMAFO2; lane 2 - LBPLSGFO3; lane 3 - LBPLSYO5; lane 4 - LBPLCAFO6; lane B - negative control without DNA. 
Table 2. Quality of Purified PCR products of phenotypically identified L. plantarum isolates.

\begin{tabular}{lccc}
\hline Sample arrangement & Sample identity & Nucleic Acid Conc. $(\boldsymbol{\mu g} / \mathbf{L})$ & $\mathbf{A 2 6 0 / 2 8 0}$ \\
\hline 1 & LBPLMAF02 & 87.9 & 1.82 \\
2 & LBPLSGF03 & 35.6 & 1.79 \\
3 & LBPLSYF05 & 41.5 & 1.77 \\
4 & LBPLCAF06 & 52.8 & 1.87 \\
\hline
\end{tabular}

Table 3. Comparison of isolated samples with other L. plantarum from gene bank.

\begin{tabular}{lclc}
\hline Sample identity & Ascension No. & Closet relatives from Gene Bank & \% similarity \\
\hline LBPLMAF02 & LC333558 & Lactobacillus plantarum KY764327.1 & 95 \\
& & Lactobacillus plantarum KY646484.1 & 95 \\
\hline LBPLSGF03 & LC333559 & Lactobacillus plantarum KY764327.1 & 97 \\
& & Lactobacillus plantarum KJ095653.1 & 97 \\
\hline LBPLSYF05 & LC333560 & Lactobacillus plantarum KY764327.1 & 96 \\
& & Lactobacillus plantarum KY764326.1 & 96 \\
\hline LBPLCAF06 & LC333561 & Lactobacillus plantarum MF429733.1 & 99 \\
& & Lactobacillus plantarum MF429677.1 & 98 \\
\hline
\end{tabular}

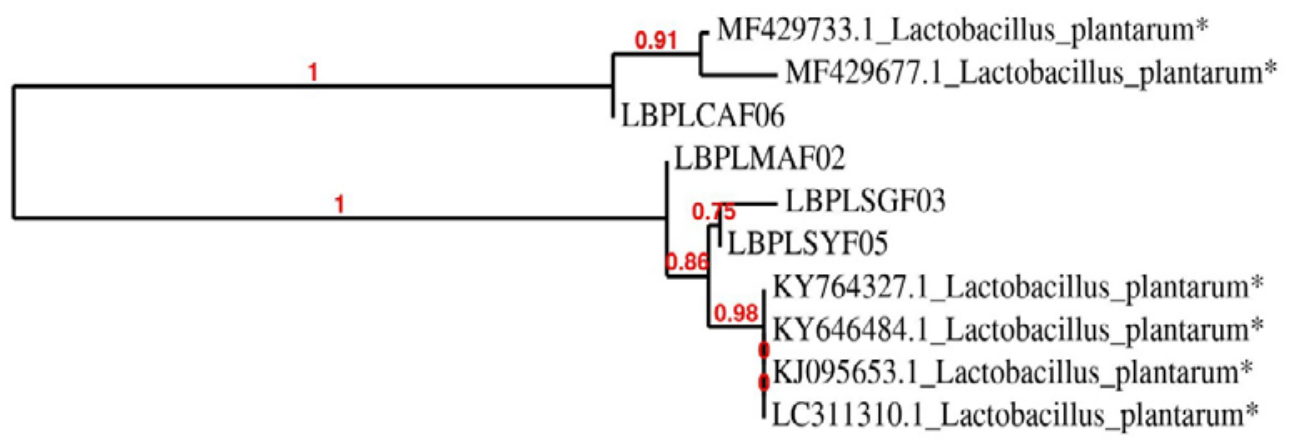

0.04

Figure 2. Construction of neighbour-joining tree of $16 \mathrm{~S}$ rDNA showing phylogenetic relatedness among L. plantarum isolates. The nucleotides of isolates with superscript * were retrieved from NCBI databank.

\section{Discussion}

In the present study, different species of lactobacilli were identified from fermented maize, sorghum, soyabeans and cassava based on their biochemical characteristics. More or less similar LAB species had been identified phenotypically from other African naturally fermented products (Gonfa et al. 2001; Saleh, 2013). This result agrees with other earlier reports that fermented foods are reservoirs of beneficial lactic acid bacteria, most of which could possess desired probiotic properties (Vieira-Dalodé et al., 2007; Argyri et al., 2013).

However, Lactobacillus species recovered in this study were observed to display inconsistencies in their sugar fermentation. For instance, although all phenotypically identified Lactobacillus plantarum fermented glucose, fructose, raffinose and sucrose but not maltose 
and lactose, these isolates further displayed their peculiarities in utilization of arabinose, dulbitol and mannitol. It is important to note that inconsistencies in sugar fermentation had been observed in other reports involving phenotypic characterisation of bacteria. The reason for this attribute is not clear from the present study, although Mohania et al. (2008) opined that bacterial isolates do not express their genes at the same time and may have even lose some important characteristics during culturing, all of which might be responsible for inconsistencies in their sugar utilization and other physiological characteristics.

The needs for adoption of more reliable methods for bacterial identification, other than conventional biochemical methods, have been clearly elucidated by numerous researchers (Fontana et al., 2005; Siezen and van Hylckama Vlieg, 2011). In addition, accurate identification of microorganisms presumed to have probiotic properties is essential, since previous reports had confirmed that probiotic effect is often specific to a particular species and even particular strain of a species (Ouwehand et al., 2002, Luyer et al., 2005). It is generally accepted that any microorganism intended to be used as probiotics should be properly classified and identified using internationally recognised methods, besides the traditional biochemical techniques.(Pineiro and Stanton, 2007).

Bacterial 16S rRNA gene sequencing is commonly used as a rapid and effective means of determining a genus- or species-level taxonomic identification of bacteria (Naser et al., 2007). Despite availability of other techniques, the use of genome sequences to characterise bacteria has been considered very useful in a number of scientific communities, as this techniques offers reduction in financial investment and expertise required to re-sequence new isolates for species that already have a representative genome-sequenced isolate.

In this study, the 16S rRNA sequencing was able to confirm the four isolates initially characterised phenotypically as L. plantarum. However, intragenomic heterogeneity of the $16 \mathrm{~S}$ rRNA gene was observed among different $L$. plantarum isolates, as the sequences of the four isolates under study had varying levels of relatedness and difference among themselves and those from databank. Similarly, previous reports on genome sequencing and comparative genomics have revealed a high genomic diversity and flexibility of L. plantarum, which is believed to contribute to its survival in diverse ecological niches (Weckx et al., 2010; Siezen and van Hylckama Vlieg, 2011). L. plantarum, as other lactic acid bacteria, has mosaic modules or cassettes of carbohydrate utilization genes, but L. plantarum seems to be very good in acquiring and shuffling these cassettes and it also allows the optimization of its genome for growth in specific niches (Di Cagno et al., 2007).

\section{Conclusion}

Both phenotypic characterization and $16 \mathrm{~S}$ rRNA sequencing employed in this study were able to characterise Lactobacillus plantarum from fermented maize, sorghum, soyabeans, and cassava. Genome diversity was also observed among these isolates, although more indepth characterisations techniques may be required for their verification as subspecies or strain. Further studies are underway in our laboratory to confirm whether or not these organisms possess similar probiotic effects on African catfish aquaculture.

\section{Conflicts of interest}

The authors declare that there are no conflicts of interest regarding this work. 


\section{References}

Anisimova, M.; Gascuel 0. Approximate likelihood ratio test for branchs: A fast, accurate and powerful alternative. Systematic Biology, v. 55, no. 4, p. 539-52, 2006.

Argyri, A. A.; Zoumpopoulou, G.; Karatzas, K. A.; Tsakalidou, E.; Nychas, G. J.; Panagou, E. Z.; Tassou C. C. Selection of potential probiotic lactic acid bacteria from fermented olives by in vitro tests. Food Microbiology, v. 33, no. 2, p. 282-291, 2013.

Castresana, J. Selection of conserved blocks from multiple alignments for their use in phylogenetic analysis. Molecular Biology Evolution, v. 17, no. 4, p. 540-552, 2000.

Chevenet, F.; Brun, C.; Banuls, A. L.; Jacq, B.; Chisten, R. TreeDyn: towards dynamic graphics and annotations for analyses of trees. BMC Bioinformatics, v. 10, no. 7, p. 439, 2006.

Cruz, P. M.; Ibáñez, A. L.; Hermosillo, O. A. M.; Saad, H. C. R. Use of probiotics in aquaculture. International Scholarly Research Network Microbiology, v. 2012, Article ID 916845, 13 p., 2012. https://doi.org/10.5402/2012/ 916845

Silva, T. L.; Gouveia, L.; Reis, A. Integrated microbial processes for biofuels and high value-added products: the way to improve the cost effectiveness of biofuel production. Applied Microbiology and Biotechnology, v. 98, no. 3, p. 1043-1053, 2014.

Deeper, A.; Audic, S.; Claverie, J. M.; Blanc, G. BLAST-EXPLORER helps you building datasets for phylogenetic analysis. BMC Evolutionary Biology, v. 12, p. 10-18, 2010.

Dereeper, A.; Guignon, V.; Blanc, G.; Audic, S.; Buffet, S.; Chevenet, F.; Dufayard, J. F.; Guindon, S.; Lefort, V.; Lescot, M.; Claverie, J. M.; Gascuel, O. Phylogeny.fr: robust phylogenetic analysis for the non-specialist. Nucleic Acids Research, v. 36, p. 465-469, 2008.

Di Cagno, R.; De Angelis, M.; Limitone, A.; Minervini, F.; Simonetti, M. C.; Buchin, S.; Gobbetti, M. Cell-cell communication in sourdough lactic acid bacteria: a proteomic study in Lactobacillus sanfranciscensis CB1. Proteomics, v. 7, no. 14, p. 2430-2446, 2007.

Edgar, R. C. MUSCLE: multiple sequence alignment with high accuracy and high throughput. Nucleic Acids Research, v. 32, no. 5, p. 1792-1797, 2004.

FAO/WHO. Food safety risk analysis: A guide for national food safety authorities. Rome: FAO/WHO, 2006. Availaible from: <ftp://ftp.fao.org/docrep/fao/009/a0822e/a 0822e00.pdf>. Accessed on: Mar. 23, 2018.

Fontana, C.; Favaro, M.; Pelliccioni, M.; Pistoia, E. S.; Favalli, C. Use of the MicroSeq 16S rRNA gene-based sequencing for identification of bacterial isolates that commercial automated systems failed to identify correctly. Journal of Clinical Microbiology, v. 43, p. 615-619, 2005.

Gonfa, F. H. A.; Holzapfel W. H. Field survey and literature review on traditional fermented milk products of Ethiopia. International Journal of Food Microbiology, v. 68, p. 173-186, 2001.

Guidone, A.; Zotta, T.; Ross, R. P.; Stanton, C.; Rea, M. C.; Parente, E.; Ricciardi, A. Functional properties of Lactobacillus plantarum strains: A multivariate screening study. LWT - Food Science and Technology, v. 56, no. 1, p. 6976, 2014

Guindon S.; Gascuel 0. A simple, fast, and accurate algorithm to estimate large phylogenies by maximum likelihood. Systematic Biology, v. 52, no. 5, p. 696-704, 2003.

Luyer, M. D.; Greve, J. W.; Hadfoune, M.; Jacobs, J. A.; Dejong, C. H.; Buurman, W. A. Nutritional stimulation of cholecystokinin receptors inhibits inflammation via the vagus nerve. Journal of Experimental Medicine, v. 202, no. 8, p. 1023-1029, 2005.

Merrifield, D.; Balcazar, J.; Daniels, C.; Zhou, Z.; Carnevali, O.; Sun, Y.; Hoseinifar, S.; Ringø, E. Indigenous lactic acid bacteria in fish and crustaceans. In: Ringø, E.; Merrifield, D. (Eds.). Aquaculture nutrition: Gut health, probiotics and prebiotics. Oxford: WileyBlackwell, 2014. p. 128-168.

Mohania, D.; Nagpal, R.; Kumar, M.; Bhardwaj, A.; Yadav, M.; Jain, S.; Marotta, F.; Singh, V.; Parkash, 0.; Yadav, H. Molecular approaches for identification and characterization of lactic acid bacteria. Journal of Digestive Disease, v. 9, no. 4, p. 190-198, 2008.

Molin G. Probiotics in foods not containing milk or milk constituents, with special reference to Lactobacillus plantarum 299v. American Journal of Clinical Nutrition, v. 73, p. 380S-385S, 2001. 
Nayak, S. K. Role of gastrointestinal microbiota in fish. Aquaculture Research, v. 41 p. 1553-1573, 2010.

Naser, S. M.; Dawyndt, P.; Hoste, B.; Gevers, D.; Vandemeulebroecke, K.; Cleenwerck, I.; Vancanneyt, M.; Swings J. Identification of lactobacilli by pheS and rpoA gene sequence analyses. International Journal of Systematic and Evolutionary Microbiology, v. 57, p. 2777-2789, 2007.

Ouwehand, A. C.; Salminen, S.; Isolauri, E. Probiotics: an overview of beneficial effects. Antonie Van Leeuwenhoek, v. 1/4, p. 279289, 2002.

Pineiro, M.; Stanton, C. Probiotic bacteria: Legislative framework - requirements to evidence basis. Journal of Nutrition, v. 3, n. 2, p. 850S-853S, 2007.

Ringø, E.; Dimitroglou, A.; Hoseinifar, S. H.; Davies, S. J. Prebiotics in finfish: an update. In: Ringø, E.; Merrifield, D. (Eds.). Aquaculture nutrition: Gut health, probiotics and prebiotics. Oxford: Wiley Blackwell, 2014. p. 360-400.

Saleh, F. A. Isolation and identification of microorganisms and antibacterial activity of Laban Zeer, an Egyptian traditional fermented milk product. Food and Nutrition Sciences, v. 2, p. 31-42, 2013.

Schleifer, K. H.; Ehrmann, M.; Beimfohr, C.; Brockmann, E.; Ludwig, W.; Amann, R. Application of molecular methods for the classification and identification of lactic acid bacteria. International Dairy Journal, v. 5, p. 1081-1094, 1995.

Siezen, R. J.; van Hylckama Vlieg, J. E. T. Genomic diversity and versatility of Lactobacillus plantarum, a natural metabolic engineer. Microbial Cell Factories, v. 10, no. 1., S1-S3, 2011. https://doi.org/10.1186/1475-2859-10-S1S3

Vankerckhoven, V.; Huys, G.; Vancanneyt, M.; Vael, C.; Klare, I.; Romond, M. B.; Entenza, J. M.; Moreillon, P.; Wind, R. D.; Knol, J.; Wiertz, E.; Pot, B.; Vaughan, E. E.; Kahlmeter, G.; Goossens, H. Bio-safety assessment of probiotics used for human consumption: recommendations from the EU-PROSAFE project. Trends in Food Science \& Technology, v. 19, no. 2, p. 102-114, 2008.

Vieira-Dalodé, G.; Jespersen, L.; Hounhouigan, J.; Moller, P.; Nago, C.; Jakobsen, M. Lactic acid bacteria and yeasts associated with gowé production from sorghum in Bénin. Journal of Applied Microbiology, v. 103, no. 2, p. 342-349, 2007.

Weckx, S.; Van der Meulen, R.; Allemeersch, J.; Huys, G.; Vandamme, P.; Van Hummelen, P.; De Vuyst, L. Community dynamics of bacteria in sourdough fermentations as revealed by their metatranscriptome. Applied Environmental Microbiology, v. 76, no. 16, p. 5402-5408, 2010. 